CUAJ honours its members and friends who have passed away. We invite colleagues of the deceased to submit brief remembrances. Please limit your notice to 200 words. Send your notice to journal@cua.org or fax it to 514-395-1664.

\section{Dr. George Stewart Murchison Wilson}

Dr. Wilson died on May 30, 2011, at the age of 96. Dr. Stewart Wilson dedicated his long life to ensuring south Niagara residents had the best health care they could get. He spent 40 years of his life working as a physician in Welland, Ontario.

Dr. Wilson born and educated in Edinburgh, Scotland and joined the British Army Medical Corps early in World War II serving in France, Nigeria and India. In 1951, he immigrated to Canada and then came to Welland to practice with his late partner and close friend, Vic Railton. He served the community in numerous capacities, including as Chief of Staff of the Welland Hospital, Medical Chairman of the Welland Hospital Building Committee, and President of the Welland Club, Welland Curling Club and Lookout Point Golf and Country Club. He was a lifelong student of urology, including as a member of the Buffalo Urological Society where he regularly participated in lectures and rounds. He was also a senior member of the Canadian Urological Association.

Dr. Wilson, who had been a surgeon in the British Army before moving to Canada, began his career in Welland working as a general surgeon at the old hospital on Riverside Drive.

Although Dr. Wilson was the first urologist to set up practice in Welland, he ensured he wouldn't be the only one. Railton said he went on to recruit additional urologists to the city, including Dr. Hagop Mazmanian and the late Dr. Ken Murray. He was instrumental in efforts to build the current Welland hospital which opened in 1960, serving as the medical chairman of the Welland Hospital Building Committee in the 1950s.

Dr. Wilson remained dedicated to improving his own knowledge and skills throughout his career, which led him to positions of increasing responsibility at the hospital ranging from chief of urology to chief of staff.

Despite his commitment to his profession and his patients, Dr. Wilson also had time to dedicate to personal interests-including his large family, woodworking and sports, including golfing, curling and sailing.

Cite as: Can Urol Assoc J 2011;5(4):292; D01:10.5489/cuaj.11139 